\title{
PEMBELAJARAN SASTRA BERKARAKTER HUMANIS UNTUK GENERASI $Z$
}

\section{LITERATURE LEARNING OF HUMANICAL, CHARACTER FOR GENERATION $Z$}

\author{
Ayyu Subhi Farahiba \\ Universitas Trunojoyo Madura \\ ayyusubhi.trunojoyo@gmail.com
}

\begin{abstract}
ABSTRAK: Generasi $\mathrm{Z}$ dikenal sebagai generasi mobile karena generasi ini tumbuh bersama kemajuan teknologi sehingga memandang teknologi adalah bagian dari mereka. Masyarakat lebih banyak berinteraksi dengan memanfaatkan smartphone daripada berkomunikasi secara langsung atau tatap muka. Apabila dibiarkan, mungkin masyarakat Indonesia akan kehilangan sikap humanis. Pembelajaran sastra penting untuk diperhatikan karena cerminan dari sebagian realitas. Pembelajaran sastra penting bagi peserta didik untuk mempelajari nilai-nilai kehidupan, salah satunya nilai humanis. Penelitian ini akan membahas pembelajaran sastra yang betkarakter humanis untuk Generasi Z. Sastra memiliki posisi penting dalam pembentukan karakter bangsa. Demikian pula dalam porsi pembentukan mental, sebab dunia dalam sastra merupakan dunia yang dibangun atas dialektika ruang keindahan dan nilai. Sastra hadir dengan fungsinya sebagai bagian untuk mendidik masyarakat. Strategi yang digunakan oleh dalam menginternalisasi nilai-nilai humanistik religius diawali dari pemahaman peserta didik melalui pembelajaran dan pembiasaan. Internalisasi nilai-nilai humanis dan pembentukan sikap dapat dilakukan melalui pembelajaran sastra dengan memanfaatkan sastra siber. Sastra siber merupakan aktivitas sastra yang memanfaatkan komputer atau internet. Keberadaan sastra siber sangat tepat untuk dimanfaatkan sebagai sarana pembelajaran sastra untuk Generasi Z. Melalui sastra siber. generasi ini dapat mengakses dan mencari informasi secara mandiri tentang karya sastra yang ingin dipelajari atau dibaca.
\end{abstract}

Kata Kunci: pembelajaran sasura, nilai humanis, Generasi $Z$.

\section{PENDAHULUAN}

Percaturan berbagai kebudayaan dalam arus globalisasi melahirkan satu, yaitu Generasi 7. Menurut Dahana (2012) Generasi $\mathrm{Z}$ adalah generasi yang telah berubah hampir setiap dimensi, bukan hanya gaya hidup, cara berpikir, kosmologi, tetapi juga dalam menatap waktu atau masa lalu dan masa depannya. Generasi $\mathrm{Z}$ adalah mereka yang yang lahir antara tahun 1998-sekarang (Tapscott, 2013: 24). Generasi $Z$ dikenal sebagai generasi mobile karena generasi ini tumbuh bersama kemajuan teknologi sehingga memandang teknologi adalah bagian dari mereka. Generasi ini disebut juga Net Generation (Tapscott, 2013: 25).
Gencrasi Z lcbih scring menggunakan IT, media sosial, dan smartphone secara aktif. Penggunaan smartphone secara aktif menjadikan generasi $\mathrm{Z}$ berbeda dengan generasi lainnya.

Generasi $Z$ menyukai kebebasan dan tidak menyukai otoritas. Generasi Z juga tidak membedakan kelompok usia maupun jenis kelamin. Berdasarkan ciri Generasi $Z$ tersebut, melangkaui tahun 2020, kemungkinan besar terdapat perubahan drastis dalam budaya kerja, etika dan nilai-nilai yang akan akan ditetapkan oleh Generasi Z. Generasi Z bukanlah pendengar yang baik dan kurang menguasai kemahiran interpersonal. Generasi ini menggunakan World Wide 
Web untuk berkomunikasi dan saling berhubungan. Apabila generasi ini bekerja kelak, kemungkinan tidak akan kelihatan berkomunikasi bersama reka atau majikan secara langsung, tetapi lebih senang berhubung melalui dunia maya. Generasi ini mampu menjalin hubungan dalam bentuk jejaring yang besar tanpa perlu mengenal siapa pun secara peribadi. Bahkan, generasi ini menganggap hidup bersama orang lain sebagai satu pencerobohan ruang.

Hasil riset menunjukkan bahwa dampak negatif dari kemajuan teknologi dan mudahnya akses intemet addah munculnya sifat konsumtif, individualistis, kurang peka terhadap lingkungan, menginginkan segala sesuatu didapatkan dengan instan (Juwita, Budimansyah, \& Nurbayani, 2015). Situasi sosial seperti ini sudah muncul di Indonesia. Masyarakat lebila banyak berinteraksi dengan memanfaatkan smartphone daripada berkomunikasi secara langsung atau tatap muka. Apabila dibiarkan, mungkin masyarakat Indonesia akan kchilangan sikap humanis.

Pendidikan sebagai lembaga sosial yang berfungsi sebagai pembentuk insan yang berbudaya dan melakukan proses pembudayaan nilai-nilai, harus senantiasa toleran dan tunduk padis perubahan normatif dan kultural yang terjadi. Melalui pendidikan, nilai-nilai karakter dapat diinternalisasikan dalam kegiatan pembelajaran. Salah satunya dalam perabelajaran sastra. Pembelajatan sastra harus menjadi daya tarik tersendiri dalam mengubah paradigma peserta didik dalam menghadapi kehidupan.

Pembelajaran sastra penting untuk diperhatikan karena cerminan dari sebagian realitas. Pembelajaran sastra penting bagi peserta didik untuk mempelajari nilai-nilai kehidupan, salah satunya nilai humanis. Tujuan yang mendasar dari pembelajaran ini adalah peserta didik mempelajari sastra bukan untuk menjadi seorang sastrawan, melainkan mampu berpikir dan bersikap kritis dalam membaca kehidupan scharihari. Agar dapat memilih bahan pembelajaran sastra dengan tepat, beberapa aspek perlu dipertimbangkan dengan baik. Aspek yang tidak boleh dilupakan dalam memilih bahan pengajaran sastra, yaitu aspek bahasa, aspek psikologi, dan aspek latar belakang budaya. Dalam pendckatan pendidikan humanistik, ketiga aspek tersebut dijelaskan dan diperhatikan dengan saksama.

Penelitian ini menggunakan pendekatan kualitatif. Penelitian kualitatif merupakan metode-metode untuk mengeksplorasi dan memahami makna yang oleh sejumlah individu atau sekelompok orang dianggap sebagai 
masalah sosial atau kemanusiaan. Penelitian ini akan membahas pembelajaran sastra yang berkarakter humanis untuk Generasi Z. Melalui penelitian ini diharapkan pendidik dapat memahami pentingnya karakter humanis diterapkan dan dimiliki oleh peserta didik, khususnya Generasi $Z$, agar di masa depan karakter humanis ini tidak luntur bahkan hilang dari jati diri bangsa Indonesia.

\section{PEMBAHASAN}

\section{Nilai Humanis dalam Karya Sastra}

Menurut Nurgiyantoro (2010:323), jenis ajaran moral dapat mencakup masalah yang boleh dikatakan bersifat tidak terbatas. Nilai-nilai humanis berkaiatan erat dengan persoalan manusia dan persoalan moral. Ajaran moral mencakup hidup dan kehidupan, yaitu permasalahan yang menyangkut harkat dan martabat manusia. Moral dala karya sastra, biasanya dimaksudkan sebagai suatu sarana yang berhubungan dengan ajaran moral tertentu, bersifat praktis, dan dapat diambil (ditafsirkan) lewat cerita yang bersangkutan oleh pembaca. Menurut Saryono (2009:57), dalam apresiasi sastra sering juga terhidang pengalaman humanistis, pengalaman manusiawi. Pengalaman humanistis ialah pengalamanpengalaman yang bermuatan nilai-nilai kemanusiaan, menjunjung harkat dan martabat manusia, serta menggambarkan situasi dan kondisi kemanusiaan. Penggambaran situasi dan kondisi kemanusiaan yang dihidangkan kepada pembaca bisa bermacam-macam, misalnya tragis, dramatis, sinis, ironis, humoris, riang, murung, garang, dan penasaran. Penggambaran itu tetap berpihak pada nilai-nilai kemanusiaan dan harkat martabat manusia.

Apabila sastra atau karya sastra dianggap tidak berguna, tidak bermanfaat lagi untuk menafsirkan dan memahami masalah-masalah dunia nyata, pengajaran sastra tidak akan ada gunanya lagi untuk diadakan (Rahmanto, 2000:15). Artinya, sastra bukan sesuatu yang kosong dan tidak berguna. Melalui paparan kisah, cerita, dan imajinasi pengarang, sastra merupakan pantulan kehidupan. Sastra merupakan refleksi nyata dari kehidupan nyata. Sastra dapat dijadikan media pendidikan. Oleh sebab itu, sastra dapat dimanfaatkan untuk menginternalisasikan dan mentransfer nilai karakter melalui penyajian sebuah karya sastra.

Wibowo (2013:129) mengatakan bahwa terdapat simpul-simpul sastra dengan pendidikan karakter. Sastra dapat digunakan sebagai media pembentuk watak moral anak didik. Karya sastra dapat menyampaikan pesan-pesan moral baik secara implisit maupun ekspilisit. Dengan mengapresiasi cerpen, novel, cerita rakyat, puisi, dan dongeng, dapat menumbuhkan 
karakter positif anak didik. Nilai-nilai kejujuran, kebaikan, persahabatan, persaudaraan, kekeluargaan, keiklasan, ketulusan, dan lain sebagainya yang berkaitan dengan pendidikan karakter dapat diterapkan melalui sastra.

Sastra memberikan sumbangan besar terhadap peradapan manusia. Karya sastra merupakan media, alat atau sarana tidak langsung untuk menerapkan pendidikan moral. Dalam hubungan ini, karya sastra memiliki fungsi yang sama, yaitu untuk mendidik masyarakat. Pendidikan karaktcr dalam konteks sastra merupakan dua hal yang sangat crat kaitannya. Sastra dengan ragam kisah dan rcalitas yang ditampilkan sesungguhnya merupakan tampilan dari kehidupan nyata. Dengan demikian sastra tidak sekadar bahan bacaan yang tidak berfungsi apaapa, sastra juga dapat scbagi media pembentukan karakter sangat nyata.

\section{Pembelajaran Sastra Berkarakter}

\section{Humanis untuk Generasi $Z$}

Pendidikan karakter pada hakikatnya merupakan pendidikan yang mengembangkan nilai-nilai budaya dan karakter bangsa pada diri peserta didik sehingga memiliki dan menerapkan nilainilai tersebut dalam kehidupan dirinya sebagai anggota masyarakat dan warga negara yang religius, produktif, dan kreatif (Sulistyowati, 2012:22). Tujuan pendidikan karakter, yaitu

mengembangkan potensi/nurani/afektif peserta didik sebagai manusia dan warga negara yang memiliki nilai-nilai budaya dan karakter bangsa; (b) mengembangkan kebiasaan dan perilaku peserta didik yang terpuji dan sejalan dengan nilai-nilai universal dan tradisi budaya bangsa yang religius; (c) menanamkan jiwa kepemimpinan dan tanggung jawab peserta didik sebagai generasi penerus bangsa; (d) mengembangkan kemampuan peserta didik menjadi manusia yang mandiri, kreatif, berwawasan kebangsaan; (e) mengembangkan lingkungan kehidupan sekolah sebagai lingkungan belajar yang aman, jujur, penuh kreativitas dan persahabatan, serta dengan rasa kebangsaam yang tinggi dan penuh kekuatan (Sulityowati, 2012:27-28). Pendidikan karakter pada hakikatnya ialah pendidikan yang mengembangkan nilainilai positif yang dapat digali dari diri manusia. Nilai-nilai tersebut bertujuan untuk mengembangkan karakter seseorang. Pengembangan kepribadian dibentuk melalui pembentukan moral agar memiliki sikap yang baik. Dengan pengertian tersebut, pada akhirnya dapat memberi kontribusi yang baik bagi kehidupan berbangsa dan bernegara.

Bacaan sangat berpengaruh terhadap pertumbuhan dan kemajuan suatu bangsa dan Ncgara. Apabila bacaan di 
negara itu bervirus mental tinggi, maka diharapkan negara itu akan tumbuh pesat 10-20 tahun kemudian, seperti sudah terjadi di Yunani Kuno (abad 6-7) dan Inggris (abad 18). Faktor pendorong kemajuan tersebut adalah dunia kesusastraan, bacaan rakyat, cerita-cerita rakyat diisi dengan tema-tema yang mendukung peningkatan kemakmuran (Widyamartaya, 2008:1). Pendapat tersebut mengasumsikan bahwa sastra mampu menjadi penggerak dalam menciptakan iklim kehidupan yang kondusif karena dalam sastra mengandung motivasi dan petuah adiluhung 'luhur' sehingga kehidupan luhur pun dapat tercipta. Sastra merupakan wacana pembentukan karakter dan dapat menjadi alat untuk membentuk moral seseorang. Melalui kehidupan yang ditampilkan di dalamnya, seseorang akan dapat mengambil teladan.

Mata pelajaran bahasa Indonesia di sckolah-sckolah telah mengajarkan tentang sastra. Namun, cara itu belum dirasa efektif dalam mendekatakan seseorang dengan sastra. Strategi yang lebih efektif yaitu mengajak seseorang tersebut agar dapat memproduksi karya sastra. Dengan langkah tersebut pada nantinya akan tumbuh daya kreatif sekaligus apresiatif. Langkah yang ditempuh ialah dapat mendirikan sanggar-sanggra sastra. Sanggar sastra dimaksudkan agar seseorang dapat lebih leluasa dalam mendekatkan diri dengan sastra. Sanggarsanggar sastra dapat didirikan, baik di lingkungan sekolah maupun pun di lingkungan masyarakat. Sanggar sastra dapat berbentuk rumah baca, rumah kreatif, taman baca, dan sebagainya. Pada intinya, sanggar sastra membentuk apresiatif dan daya kreatif melalui sastra.

Sastra memiliki posisi penting dalam pembentukan karakter bangsa. Demikian pula dalam porsi pembentukan mental, sebab dunia dalam sastra merupakan dunia yang dibangun atas dialektika ruang keindahan dan nilai. Sastra hadir dengan fungsinya sebagai bagian untuk mendidik masyarakat. Menurut (Ratna, 2014: 209) mengatakan bahwa karya sastra bersumber dari fungsifungsi karya sastra. Karya sastra sebagai kreativitas imajinatif yang sesungguhnya dari masyarakat, demikian juga karya budaya sebagai warisan, baik secara mandiri maupun proses antarhubungan, merupakan sumber utama karya pendidikan karakter. Dalam konteks ini, wahana edukatif karya sastra ialah media dalam pembentukan karakter, baik pemahaman terhadap budaya bangsa maupun terhadap nilai-nilai yang terkandung dalam kebudayaan.

Sastra tidak hanya dipandang sebagai sebuah karya seni bahasa yang kosong nilai. Akan tetapi tidak demikian 
sempit, sastra sebagai hasil budaya sangat memiliki peran penting terhadap perkembangan kebudayaan. Bentuk realitas, nilai kemasyarakatan, sampai dengan keragaman kebudayaan suatu masyarakat merupakan aspek yang patut untuk kembali digali sebagai penguatan kebudayaan. Melihat hal ini, Wibowo (2013: 109) sastra harus bias berperan human control persoalan-persoalan yang terjadi di masyarakat. Pandangan ini jelas sangat sesudi dengan prinsip bahwa setiap karya sastra yang dihasilkan oleh sastrawan terkandung misi. Dalam konteks demikian, Ratna (2014: 209) memberi penegasan bahwa setiap aktivitas memiliki fungsi, tujuan, dan hasil akhir, termasuk evaluasi dalam rangka perkembangan aktivitas tcrsebut. Demikian pula halnya sastra, relevansinya ditunjukkan melalui makna tambah yang berhasil ditunjukkan, baik olch pccipta, scbagai subjektivitas, maupun penikmat, sebagai makna subjektivitas sekaligus objektivitas.

Sastra yang merupakan bentuk ekspresi dan komunikasi yang digambarkan dalam fiksionalitas, akan tetapi sastra dituntut mengandung nilainilai kehidupan yang adilung sebagai bagian pendidikan karakter. Berkaitan dengan sastra mengandung nilai adiluhung, Wibowo (2013: 104) memberi batasan, bahwa sastra adiluhung adalah dunia yang bersifat dinamis, relatif, dan bukan ekslusif. Nilai sastranya pasti terkait dengan kepribadian manusia. Karena ketinggian tingkat apresiasinya, sastra adiluhung sangat bermutu lantaran mampu menghaluskan rohaniah; mempertajam visi, misi dan ruang imajinasi, membuat manusia santun jiwanya, bertambah pengetahuannya, berkepribadian mulia, dan luas jiwanya. Oleh scbab itu, ada yang mengatakan bahwa peran sastra sebagai Fumun control guna mengembalikan martabat manusia, baik di mata manusia lain, maupun di sisi Tuhan. Sastra adalah ruang pencarian dan bentuk pemikiran kritis yang dalam nuang terscbut mengemban nilai-nilai spiritual, kemanusiaan, sosial, serta nilai hakiki kehidupan lain. Maka dengan bahasa sebagai mediumnya, diharapkan satrawan harus mampu menghindari kepicangan ranah yang tanpa makna. Bahasa difungsikan satrawan sebagai bentuk olah pikir schingga misi luhur yang diupayakannya dapat tertuang. Misi luhur tersebut adalah mengasah karakter kebangsaan pada generasi muda.

Usaha untuk menyiapkan generasi yang berkarakter di tengah era globalisasi saat ini, pendidikan yang mengarah pada pembentukan karakter kebangsaan sangat urgen dilakukan. Pertukaran informasi tidak disadari membawa pula pengaruh kebudayaan dari masyarakat bangsa dari belahan dunia. Pengadopsian terhadap 
nilai dari budaya lain pun tidak bisa terhindarkan oleh generasi bangsa. Untuk mengatasi fenomena tersebut, pemerintah benusaha mengantisipasi generasi digital dan usaha sadar merespon kehidupan global dengan menerapkan Kurikulum 2013.

Mempertimbangkan dua aspek penting di atas, yakni mengenai nilai humanis dalam Kurikulum 2013 dan sastra sebagai basis pembentukan karakter kebangsaan, kiranya sangat perlu dipadukan untuk diterapkan pada Generasi $\mathrm{Z}$ saat ini. Indonesia sebagai negara yang menjunjung tinggi nilai kemanusiaan harus gencar dalam mempcrkuat nilai tersebut. Karya sastra para pengarang sastra banyak yang mengangkat dan mengintegrasikan nilai kemanusiaan dalam karya sastranya. Oleh sebab itu, pedoman pembelajaran sastra sangat penting untuk mempertimbangkan materi pembelajaran sastra yang sarat akan nilai kearifan lokal bangsa.

Dalam hal ini, pembelajaran kontekstual dapat memberi dukungan terhadap pembelajaran sastra berbasis nilai humanis. Pembelajaran kontekstual merupakan konsep belajar yang membantu pendidik dalam mengaitkan materi pembelajaran dengan situasi dunia nyata peserta didik dan mendorong peserta didik membuat hubungan antara pengetahuan yang dimilikinya dengan kchidupan anggota keluarga dan masyarakat. Dalam proses pembelajaran, tugas pendidik mengelola kelas sebagai tim yang bekerja bersama untuk menemukan sesuatu yang baru bagi peserta didik. Pengetahuan dan keterampilan yang diperoleh menupakan hasil kerja mandiri peserta didik berdasarkan konsep yang dikaitkan dengan kondisi lingkungan tempat tinggalnya. Peran peserta didik mengontruksi informasi-informasi yang diperoleh untuk diformulasikan menjadi pengetahuan dan keterampilan yang dimiliki. Pembelajaran kontekstual dapat dipadukan dalam pembelajaran sastra berbasis nilai humanis. Cara ini memberi peluang peserta didik dalam mengenal, menggali, dan menyerap nilai humanis dalam pembelajaran sastra.

Strategi yang digunakan oleh dalam menginternalisasi nilai-nilai humanistik religius diawali dari pemahaman peserta didik melalui pembelajaran dan pembiasaan. Tahapan pembelajaran dan pernbiasaan melalui proses moral knowing, moral feeling, dan moral action. Strategi yang digunakan oleh guru sesuai dengan konsep pendidikan karakter Lickona, dimana orientasi pendidikan mengarah pada tiga komponen karakter yaitu pengetahuan moral (moral knowing), perasaan moral (moral feeling) dan tingkah laku moral (moral behavior)(Lickona, 2015: 85-100). 
Sebagai contoh ketika seorang guru mengajarkan tentang berbuat baik kepada sesama manusia, belum tentu peserta didik serta merta pada saat itu juga langsung berbuat baik. Mengajarkan peserta didik berbuat baik merupakan bagian dari tahap pengetahuan moral (moral knowing). Agar pengetahuan moral (moral knowing) menjadi sebuah perasaan moral (moral feeling), maka guru perlu membiasakan peserta didik berbuat baik. Ketika peserta didik sudah terbiasa berbuat baik maka diharapkan akan melahirkan kebiasaan sikap berbuat baik atau pada tahap tingkah laku moral (moral behavior). Proses internalisasi nilai-nilai humanistik religius diawali berawal dari kognitif, bukan berarti metode yang dipakai hanya menggunakan metode konvensional atau ceramah. Dalam menginternalisasi nilainilai humanistik religius dan membina akhlak dapat dilakukan dengan berbagai metode. Hal ini sesuai dengan penelitian sebelumnya yang menuntut guru harus memiliki kompetensi pedagogik.

Fenomena munculnya Generasi $Z$ yang tidak dapat terlepas dari gadget berdampak pada kurang konsentrasi, kurang keterlibatan, dan kurangnya sosialisasi dalam proses pembelajaran. Kompetensi pedagogik guru menjadi sangat penting dalam memotivasi peserta didik, mengajar dengan cara yang kreatif dan mengelola pembelajaran.
Kecenderungan Generasi $Z$ dengan smartphone bukan berarti peserta didik dilarang dan dijauhkan dari smartphone selama pembelajaran. Guru dapat menjadikan smartphone sebagai sumber belajar bagi peserta didik, tentunya dengan pengawasan dan bimbingan guru.

Internalisasi nilai-nilai humanis dan pembentukan sikap dapat dilakukan melalui pembelajaran sastra dengan memanfaatkan sastra siber. Sastra siber merupakan aktivitas sastra yang memanfaatkan komputer atau internet. Keberadaan sastra siber sangat tepat untuk dimanfaatkan sebagai sarana pembelajaran sastra untuk Generasi Z. Melalui sastra siber, generasi ini dapat mengakses dan mencari informasi secara mandiri tentang karya sastra yang ingin dipelajari atau dibaca. Peserta didik mengakses dan mencari tahu sendiri karya sastra melalui sastra siber. Namun, guru tetap harus memperhatikan aktivitas pescrta didik. Peserta didik tidak dapat dilepaskan begitu saja dalam mengakses informasi. Guru harus mengawasi dan mengarahkan peserta didik untuk tetap mendiskusikan informasi yang telah diperoleh bersama dengan teman sejawat. Dengan demikian, peserta didik tidak hanya berkomunikasi melalui dunia maya tetapi juga berkomunikasi secara langsung dalam dunia nyata. 


\section{PENUTUP}

Modernisme menjadikan manusia bergantung kepada teknologi. Teknologi melahirkan manusia yang jauh dari nilai humanis. Strategi dalam menginternalisasi nilai-nilai humanis untuk Generasi Z adalah melalui proses pembelajaran di kelas yang dilakukan dengan berbagai macam metode dan media berbasis teknologi yang disesuaikan dengan karakter Generasi Z. Proses pendidikan juga dilakukan dengan pembiasaan akhlak mulia di lingkungan sekolah, pemberlakuan hukuman yang mendidik dan humanis, juga melalui komunikasi pihak sekolah dengan orang tua. Namun sangat disayangkan dalam menumbuhkan pembiasaan akhlak mulia dan internalisasi nilai-nilai humanis masih belum digiatkan.

Guru perlu menyusun strategi dan metode pembelajaran yang lebih kreatif dengan mengedepankan kolaboratif. Salah satu metode yang tepat dalam menginternalisasi nilai-nilai humanis pada Generasi $Z$ yang cenderung berada di dunia maya dan jauh dari dunia realita adalah menggunakan metode pembelajaran kontekstual. Hal ini bertujuan agar peserta didik menjadi pribadi yang lebih baik, bersemangat dalam belajar, mendapat pengalaman, pribadi yang lebih baik, taat beragama, lebih peduli terhadap isu kemanusiaan dan berusaha berkolaborasi dalam mencari solusi. Pembelajaran sastra di sekolah dapat memanfaatkan sastra siber. Melalui sastra siber, peserta didik menjadi lebih mudah dalam mengakses informasi maupun karya sastra. Selain mengurangi masalah yang muncul di sekitar, virus kepedulian ini dapat ditularkan melalui media sosial yang Generasi $Z$ miliki. Apabila hal ini dilakukan di setiap sekolah, sedikit demi sedikit permasalahan akan berkurang. Selain itu, penggunaaan smartphone dan teknologi internet oleh Generasi Z mengarah kepada hal lebih positif.

\section{DAFTAR PUSTAKA}

Dahana, Radhar Panca. 2012. "Generasi Digital". Dalam Kompas, Minggu, 28 November.

Juwita, E. P., Budimansyah, D., \& Nurbayani, S. 2015. Peran Media Sosial terhadap Gaya Hidup Siswa SMAN 5 Bandung. Jurnal Sosietas, $V(1), 1-8$.

Lickona, T. 2015. Educating for Character : Bagaimana Sekolah Dapat

Mengajarkan Sikap Hormat dan

Tanggung Jawab. (J. A. Wamaungo, Penerj-) Jakarta: Bumi Aksara.

Nurgiantoro, B. 2010. Teori Pengkajian

Fiksi. Yogyakarta: Gajah Mada

University.

Rahmanto, B. 2000. Metode Pengajaran

Sastra. Yogyakarta: Kanisius. 
Ratna, Nyoman Kutha. 2014. Peranan

Karva Sastra, Seni, dan Budaya

dalam Pendidikan Karakter.

Yogyakarta: Pustaka Pelajar.

Saryono, J. 2009. Dasar Apresiasi

Sastra.Yogyakrta: Elmatera

Publishing.

Sulistyowati, Endah. 2012. Implementasi

Kurikulum Pendidikan Karakter.

Yogyakarta: Citra Adi Parama.
Taspcott, Don. 2008. Grown Up Digital:

How the Net Generation is Changing

Your World. McGraw-Hill.

Wibowro, Agus. 2013. Pendidikan

Karakter Berbasis Sastra.

Yogyakarta: Pustaka Pelajar.

Widyamartaya, A., B.A. 2008. Kreatif

Mengarang. Yogyakarta: Kanisius. 